Provided for non-commercial research and education use. Not for reproduction, distribution or commercial use.

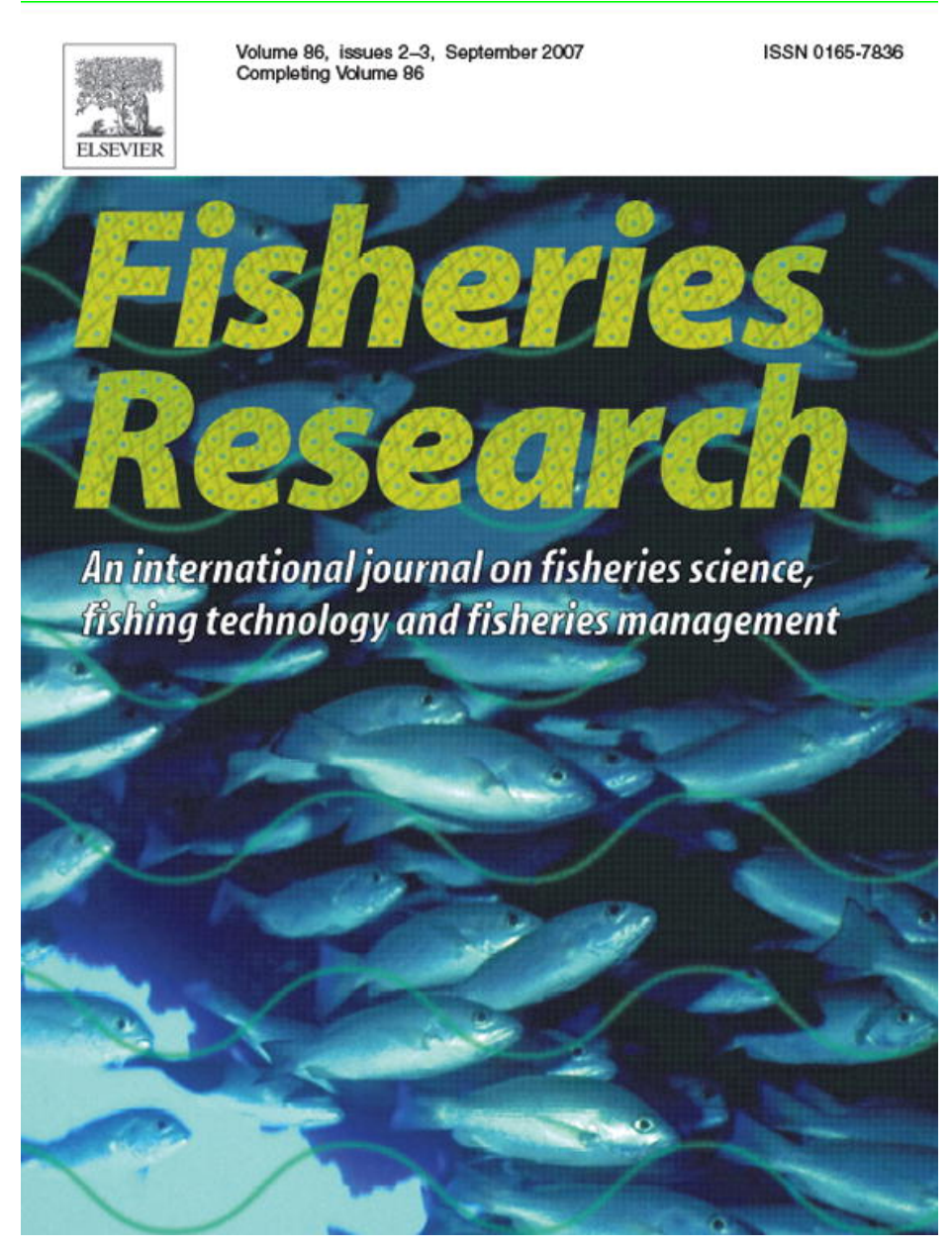

This article was published in an Elsevier journal. The attached copy

is furnished to the author for non-commercial research and education use, including for instruction at the author's institution, sharing with colleagues and providing to institution administration.

Other uses, including reproduction and distribution, or selling or licensing copies, or posting to personal, institutional or third party websites are prohibited.

In most cases authors are permitted to post their version of the article (e.g. in Word or Tex form) to their personal website or institutional repository. Authors requiring further information regarding Elsevier's archiving and manuscript policies are encouraged to visit: 


\title{
Evaluation of the interactive effects of air exposure duration and water temperature on the condition and survival of angled and released fish
}

\author{
Andrew J. Gingerich ${ }^{\mathrm{a}, \mathrm{b}}$, Steven J. Cooke ${ }^{\mathrm{a}, \mathrm{b}, *}$, Kyle C. Hanson ${ }^{\mathrm{b}}$, Michael R. Donaldson ${ }^{\mathrm{b}}$, \\ Caleb T. Hasler ${ }^{\text {b,c }}$, Cory D. Suski ${ }^{c, d}$, Robert Arlinghaus ${ }^{\mathrm{e}}$ \\ a Institute of Environmental Science, Carleton University, Ottawa, ON, Canada K1S 5B6 \\ ${ }^{\mathrm{b}}$ Fish Ecology and Conservation Physiology Laboratory, Department of Biology, \\ Carleton University, Ottawa, ON, Canada K1S $5 B 6$ \\ c Department of Biology, Queen's University, Kingston, ON, Canada K7L 3N6 \\ ${ }^{\mathrm{d}}$ Department of Natural Resources and Environmental Sciences, University of Illinois, Urbana, IL 61801, USA \\ ${ }^{\mathrm{e}}$ Leibniz Institute of Freshwater Ecology and Inland Fisheries, Forschungsverbund Berlin e.V., Berlin 12587, Germany
}

Received 14 April 2007; received in revised form 27 May 2007; accepted 1 June 2007

\begin{abstract}
At present, there is a reasonable understanding of the independent effects of catch-and-release $(C \& R)$ angling stressors, such as air exposure and water temperature, on endpoints such as physiological disturbance, behavioural impairment and mortality. However, little is known about the multiplicative or interactive nature of these different C\&R stressors. This study used bluegill (Lepomis macrochirus) as a model to evaluate the combined effects of water temperature and air exposure on fish behaviour, equilibrium status and short-term mortality following C\&R. Experiments were replicated over 3 days with different ambient water temperatures $\left(18.3,22.8\right.$ and $\left.27.4{ }^{\circ} \mathrm{C}\right)$. On each day, fish were captured by standard angling techniques, exposed to a range of air exposure durations $(0,30,60,120,240,480$ and $960 \mathrm{~s})$, and subsequently monitored for behavioural changes (within the first $300 \mathrm{~s}$ ) and short-term ( $48 \mathrm{~h}$ ) delayed mortality. Additional fish were captured by seine net for use as controls. There was an interactive effect of temperature and air exposure, whereby fish exposed to the highest temperature and longer air exposure durations lost equilibrium more often and had depressed ventilation rates relative to fish exposed to minimal air exposure and the lowest temperature. Immediate mortality at the lowest temperatures was negligible. However, significant delayed mortality (up to $80 \%$ ) was noted at the highest water temperature $\left(27.4{ }^{\circ} \mathrm{C}\right.$ ) in fish exposed to the three longest air exposure groups. In addition, at $27.4^{\circ} \mathrm{C}$, mortality among fish exposed to 480 and $960 \mathrm{~s}$ occurred at a faster rate than in any other treatment group. These results indicate that at low to moderate water temperatures, extended air exposure for bluegill may result in little mortality. However, at high water temperatures, short-term mortality (within $48 \mathrm{~h}$ ) can be substantial, especially for fish that experience extended air exposure durations. Anglers and managers must recognize that $C \& R$ stressors can interact to have more dire consequences than when applied independently.
\end{abstract}

(C) 2007 Elsevier B.V. All rights reserved.

Keywords: Air exposure; Water temperature; Catch-and-release; Equilibrium; Mortality

\section{Introduction}

Research evaluating the effects of catch-and-release (C\&R) angling on fish and fisheries has increased dramatically in recent years (summarized in Muoneke and Childress, 1994; Bartholomew and Bohnsack, 2005; Cooke and Suski, 2005; Arlinghaus et al., 2007), reflecting a growing interest in reducing

\footnotetext{
* Corresponding author at: Department of Biology, Carleton University, 1125 Colonel By Dr., ON, Canada K1S 5B6. Tel.: +613 520 2600x2143.
}

E-mail address: Steven_Cooke@carleton.ca (S.J. Cooke). mortality as well as sublethal consequences (e.g., stress, injury, behavioural alterations, fitness impairments (Cooke and Suski, 2005)). Several recent syntheses have identified air exposure and water temperature as two of the most prominent factors affecting fish survival and stress associated with C\&R angling events (Bartholomew and Bohnsack, 2005; Cooke and Suski, 2005; Arlinghaus et al., 2007). Research on bycatch in the commercial fishing sector has evaluated the interactive effect of air exposure and water temperature (e.g., Ross and Hokenson, 1997; Davis et al., 2001). However, to date, no studies have systematically evaluated the interactive effects of air exposure duration and water temperature in a C\&R angling context. Considering the 
independent negative consequences of long air exposure durations and high water temperature on angling, there is a need to understand how these two factors interact to provide realism to C\&R research (Cooke and Schramm, 2007).

High water temperature has been shown to impact $C \& R$ fisheries, as angling at high water temperatures is associated with increased physiological disturbances and probability of immediate or delayed mortality (reviewed in Cooke and Suski, 2005). Typically, higher water temperatures are associated with a number of physiological changes at the cellular level and organismal level including altered enzymatic function and elevated metabolic rate (Fry, 1971; Prosser, 1991; Somero and Hofmann, 1996). When combined with the stress and exercise associated with $C \& R$ angling, high water temperature often leads to a suite of behavioural and physiological changes. Behavioural changes may include a lack of movement or equilibrium loss (see S.E. Danylchuk et al., 2007) and physiological changes can include increases in cardiac output (heart rate and stroke volume; Anderson et al., 1998; Schreer et al., 2001) and alterations in blood and muscle biochemistry (Wilkie et al., 1996, 1997). There are also clear relationships between high water temperature and probability of post-release mortality (e.g., Wilkie et al., 1997; Anderson et al., 1998; Wilde, 1998; Thorstad et al., 2003). Reduced concentrations of dissolved oxygen which tend to occur at high water temperatures can impair post-release recovery (Killen et al., 2006; Suski et al., 2006). Currently, some jurisdictions regulate $\mathrm{C} \& \mathrm{R}$ fisheries at high temperatures as a strategy to reduce stress and mortality (summarized in Arlinghaus et al., 2007).

Air exposure has long been assumed to be harmful to fish. Typically, air exposure occurs when anglers remove the fish from the water to remove fishing hooks/lures, admire, photograph and weigh/measure the fish (Cooke and Suski, 2005). During this time, the gill lamellae collapse leading to adhesion of the gill filaments and physiological changes including acidosis, hemoglobin increase and shifts in blood gasses (Boutilier, 1990; Ferguson and Tufts, 1992; Suski et al., 2004). In addition, the duration of air exposure influences the recovery time for cardiovascular variables (Cooke et al., 2001, 2002a) and blood and muscle parameters (Suski et al., 2004; Killen et al., 2006), which can lead to impairments in swimming performance (Schreer et al., 2005). In a laboratory setting, extended air exposure after exercise similar to that induced during C\&R angling caused higher mortality than when air exposure was avoided (Ferguson and Tufts, 1992). In a pond study, mortality was lowest for fish that were not exposed to air relative to air exposure periods of 60,120 or $240 \mathrm{~s}$ (Arlinghaus and Hallermann, 2007). In field settings, extended air exposure has been implicated in loss of equilibrium and post-release predation (Cooke and Philipp, 2004; S.E. Danylchuk et al., 2007). Though studied in laboratory settings, field studies evaluating the consequences of air exposure on fish have rarely occurred.

Here, bluegill (Lepomis macrochirus) were used as a model to determine the magnitude and nature of possible interactions between water temperature and air exposure duration on a suite of sublethal indicators and subsequent short-term mor- tality. Bluegill were chosen as a model species for several reasons, including the fact that they are actively pursued by many recreational anglers (Barthel et al., 2003; Cooke et al., 2003), and inhabit waters that experience dramatic seasonal changes, providing an opportunity to assess responses across a broad thermal range similar to multiple economically important warmwater game fish species (e.g., black bass Micropterus spp., crappie Pomoxis spp., muskellunge, Esox masquinongy, etc.). They are also extremely abundant, leading to ease of capture and manipulation for experimental purposes (both via angling and seining to capture control fish). For the purposes of this study, behavioural observations were made including the ability to maintain equilibrium, ventilation rate, time required to recover from equilibrium loss, and immediate $(1 \mathrm{~h})$ and short-term $(48 \mathrm{~h})$ mortality to determine the interactive effect of temperature and air exposure on bluegill. Using this approach, the current study evaluated the hypothesis that the interaction between water temperature and air exposure would be more detrimental to fish than if either stressor was applied independently. Specifically, it was predicted that individuals angled at the warmest water temperatures and exposed to the longest durations of air exposure would display the most extensive sublethal effects and experience the highest levels of mortality.

\section{Methods}

\subsection{Sampling}

Sampling occurred on Lake Opinicon at the Queen's University Biological Station, located in southeastern Ontario. The lake is mesotrophic, with a game fish community comprised mainly of largemouth bass (M. salmoides), smallmouth bass ( $M$. dolomieu), northern pike (E. lucius), black crappie (P. nigromaculatus), pumpkinseed (L. gibbosus) and bluegill. Sampling took place from a series of large docks or aboard a $4 \mathrm{~m}$ barge. All angling was focused in the littoral zone at a depth of approximately $0.5-1.5 \mathrm{~m}$. The experiment was replicated on 3 days (May 11, June 1 and July 18, 2006), which provided three different water temperature treatments $\left(18.3,22.8\right.$ and $27.4^{\circ} \mathrm{C}$, respectively). Temperatures on the day of angling (noted in previous sentence) were observed using a digital thermometer in a secondary monitoring tank (SMT) with fresh lake water flowing through at 13:00 $\mathrm{h}$ on the day of capture. Water temperatures during the $48 \mathrm{~h}$ monitoring period were assessed using a fixed temperature monitoring station (depth $1 \mathrm{~m}$ ) and reported as hourly means ( \pm S.E.; first holding period, $17.3 \pm 0.1{ }^{\circ} \mathrm{C}$, second holding period, $22.2 \pm 0.1^{\circ} \mathrm{C}$, third holding period, $27.7 \pm 0.1^{\circ} \mathrm{C}$ ). Anglers used standardized gear consisting of medium action spinning rods and reels with $3.63 \mathrm{~kg}$ test monofilament line. All rods were rigged with small balsa spring floats (76 mm stem) placed between 50 and $100 \mathrm{~cm}$ above the hook (size 6 Mustad hooks, model 92141, non-offset small "J" style bait hook). A single $3 / 0$ weight was positioned $15 \mathrm{~cm}$ above the hook. Hooks were baited with commercially available crappie bait (Crappie Nibbles, Berkley Inc.) measuring $5 \mathrm{~mm} \times 5 \mathrm{~mm}$ and weighing about $0.2 \mathrm{~g}$ each. This configuration has previously been used to capture bluegill in Lake Opinicon yielding 
negligible hooking mortality and injury across a broad size range of fish (Cooke et al., 2003, 2005).

In an effort to standardize angling durations, all anglers participating in the experiments were experienced at angling for sunfish, as previous research has revealed that angler experience can influence injury and hooking mortality (Dunmall et al., 2001). Fish were briefly angled, with fighting time standardized to $10 \mathrm{~s}$, to represent a moderate intensity angling event (i.e., all fish fought for $10 \mathrm{~s}$ except for the seined controls). For the purpose of this study, we wanted to eliminate the duration of the exercise event as a covariate. All fish that were hooked in areas other than the upper or lower jaw were live released and not included in subsequent analyses due to the possible effects of foul or deep hooking on behaviour, injury and mortality (Cooke et al., 2003, 2005). Additionally, only fish with no observable bleeding were used in the experiments.

Captured fish were systematically assigned to one of seven air exposure durations: 0, 30, 60, 120, 240, 480 and 960 s. The air exposure durations were selected to mimic a range of angler abilities and behaviours (e.g., from those who are experienced at removing hooks and releasing fish quickly, to those anglers who are not experienced and are more likely to subject fish to longer durations of air exposure during lengthy hook removal and photography). Fish were exposed to treatments in this standardized order and the rotation repeated sequentially throughout the day to ensure there was no bias in air exposure duration during a particular part of the day. During the air exposure, fish were measured for total length ( $\mathrm{mm}$ ), and given a binary spine or fin clip (using a surgical scissor) for subsequent identification of individuals (Conover and Sheehan, 1999; Cooke et al., 2005). Fish were then placed in a small bucket, free of debris, water (but not dry), and other fish for the remainder of their air exposure duration during which fish remained still aside from random periods of flopping. Control fish (both angled and seined) were clipped and measured under water. Measurement and fin clipping for fish that had $0 \mathrm{~s}$ of air exposure including the seined control group (see below) was done underwater in a water-filled trough. The seined control group was used to supplement the angled control group as recent publications (e.g., Cooke and Schramm, 2007) have emphasized the importance of control groups when conducting C\&R studies. Upon completion of air exposure, fish were placed in a $20 \mathrm{~L}$ primary monitoring cooler (PMC) containing fresh lake water at ambient temperature. Within the PMC, fish were observed at five different time intervals $(0,30,60,180$ and $300 \mathrm{~s})$. At each interval, fish behaviour and condition was categorized as:

(1) fish appeared normal,

(2) fish swam rapidly and randomly in the tank; somewhat erratic,

(3) fish rested on the bottom of the tank,

(4) fish displayed partial lateral equilibrium loss,

(5) fish displayed complete equilibrium loss (either floating on its side or upside down).

The five observed values were subsequently summed to give a primary equilibrium condition score during the first 300 s post- air exposure ranging from 5 (completely normal condition) to 25 (complete equilibrium loss for entire period in PMC). Throughout the sampling period, the PMC were randomly rotated to avoid potential tank effects. For all fish, the time required to regain equilibrium was also recorded. Once the $300 \mathrm{~s}$ primary monitoring time period expired, researchers counted the number of opercular movements of each fish for $30 \mathrm{~s}$. During this sampling period, research personnel maintained the same role to prevent any bias transfer and ensure consistency throughout the process (e.g., processors remained processors; timing and collecting the response variables).

After the fish were processed, they were placed for no more than $2 \mathrm{~h}$ in a large cooler $(150 \mathrm{~L})$ supplied with ambient lake water, for holding and transit to the secondary monitoring tank. During this period, immediate mortality was assessed $(1 \mathrm{~h}$ posttreatment). For the purposes of this experiment, mortality was judged as a complete cessation in ventilation. All fish were then transferred from the large cooler into the SMT $(1031 \mathrm{~L})$ with a continuous supply of fresh lake water (complete flushing every $14 \mathrm{~min}$ ) and held for subsequent observation. The tank water temperature was measured twice daily and was found to deviate from the lake temperature by less than $0.2{ }^{\circ} \mathrm{C}$. The tank was situated outside (to ensure natural photoperiod) and covered with a fine mesh to prevent avian predation attempts on treated fish. An additional set of control fish, captured by seine net on the same day as the angled fish, were also placed in the SMT. The controls were seined from the littoral zone in an area characterized by sand and gravel substrate. These controls were treated in the same manner as the $0 \mathrm{~s}$ air exposure treatment groups. For $48 \mathrm{~h}$ following sampling, at $6 \mathrm{~h}$ intervals, mortalities observed in the SMT were removed and identified based on individual binary fin clip codes and verified with total length measurements. At the end of the $48 \mathrm{~h}$ secondary monitoring period, surviving fish were visually inspected for general condition and released.

\subsection{Analysis}

JMP IN (V. 4.0, SAS Institute, Cary, NC) software was used for all statistical tests, and the level of significance for all tests $(\alpha)$ was assessed at 0.05 (Zar, 1984). All figures display mean \pm S.E. unless otherwise stated. To test for differences in total length, a two-way analysis of variance was completed using air exposure group and water temperature treatment as independent variables and length as a response (Zar, 1984). In addition, two $t$-tests (assuming unequal variances) were conducted on survivors and non-survivors in the 240 and $480 \mathrm{~s}$ air exposure groups from the last temperature treatment day $\left(27.4{ }^{\circ} \mathrm{C}\right)$ to verify the independence of size and mortality (Zar, 1984). These two groups were chosen for this analysis because they had similar proportions of mortalities to surviving fish after the $48 \mathrm{~h}$ monitoring period.

To test for the existence of the interactive effect of air exposure and water temperature on the three sublethal observations (mean condition equilibrium score, mean time to recover from equilibrium loss and opercular movement post-primary monitoring) two-way ANOVA's followed by Tukey's HSD post hoc tests were used. Three Chi Square contingency table analyses were used to determine if there were significant differences in the 
Table 1

Total number of bluegill processed separated by each temperature treatment and air exposure group, including delayed mortality and delayed mortality proportions

\begin{tabular}{|c|c|c|c|c|c|c|c|c|c|}
\hline \multirow[t]{2}{*}{ Air exposure group (s) } & \multicolumn{3}{|c|}{ Day 1: $18.3^{\circ} \mathrm{C}$} & \multicolumn{3}{|c|}{ Day $2: 22.8^{\circ} \mathrm{C}$} & \multicolumn{3}{|c|}{ Day 3: $27.4^{\circ} \mathrm{C}$} \\
\hline & $\begin{array}{l}\text { Total fish } \\
\text { caught }\end{array}$ & $\begin{array}{l}\text { Total } \\
\text { mortality }\end{array}$ & $\begin{array}{l}\% \text { Mortality } \\
\text { in group }\end{array}$ & $\begin{array}{l}\text { Total fish } \\
\text { caught }\end{array}$ & $\begin{array}{l}\text { Total } \\
\text { mortality }\end{array}$ & $\begin{array}{l}\% \text { Mortality } \\
\text { in group }\end{array}$ & $\begin{array}{l}\text { Total fish } \\
\text { caught }\end{array}$ & $\begin{array}{l}\text { Total } \\
\text { mortality }\end{array}$ & $\begin{array}{l}\% \text { Mortality } \\
\text { in group }\end{array}$ \\
\hline $\mathrm{C}$ & 25 & 0 & 0.00 & 21 & 0 & 0.00 & 14 & 3 & 21.43 \\
\hline 0 & 19 & 0 & 0.00 & 20 & 0 & 0.00 & 15 & 0 & 0.00 \\
\hline 30 & 19 & 0 & 0.00 & 20 & 0 & 0.00 & 15 & 4 & 26.67 \\
\hline 60 & 19 & 0 & 0.00 & 20 & 1 & 5.00 & 15 & 4 & 26.67 \\
\hline 120 & 18 & 0 & 0.00 & 20 & 0 & 0.00 & 15 & 3 & 20.00 \\
\hline 240 & 18 & 0 & 0.00 & 20 & 1 & 5.00 & 14 & 7 & 50.00 \\
\hline 480 & 18 & 2 & 11.11 & 20 & 0 & 0.00 & 14 & 9 & 64.29 \\
\hline 960 & 18 & 2 & 11.11 & 20 & 1 & 5.00 & 15 & 12 & 80.00 \\
\hline Sum & 154 & 4 & 2.60 & 161 & 3 & 1.86 & $123^{\mathrm{a}}$ & $48^{\mathrm{a}}$ & $39.02^{\mathrm{a}}$ \\
\hline Total fish & & 438 & & & & & & & \\
\hline Total mortality & & 55 & & & & & & & \\
\hline
\end{tabular}

${ }^{a}$ Forty-eight fish died within $48 \mathrm{~h}$ of capture (123 processed), however six fish were not included in the totals for their respective air exposure groups as rapid body decomposition occurred at this temperature and their fin clips were unidentifiable.

number of delayed mortalities among each treatment group during each of the temperature treatments days. Due to rapid body decomposition at the highest water temperature, some fin clips were un-readable $(n=6)$ and thus were excluded from analyses. When significant mortality was found on a given temperature treatment day, differences in fish survival were examined with contingency table analyses. In addition, a Wilcoxon univariate survivor analysis with censoring ( $48 \mathrm{~h}$ ) was used to assess the relationship between air exposure duration and time to mortality for the warmest temperature group $\left(27.4{ }^{\circ} \mathrm{C}\right)$.

\section{Results}

Overall, 438 bluegill were captured and processed across the three temperature treatments (Table 1). Differences between sizes of fish in each treatment group across the sampling days were observed (two-way ANOVA: d.f. $=14, F=1.80, P=0.037$; Table 2). Specifically, control fish captured in the seine net during the first $\left(18.3^{\circ} \mathrm{C}\right)$ and last $\left(27.4^{\circ} \mathrm{C}\right)$ temperature treatment were consistently smaller than those in the other air exposure groups, accounting for nearly $90 \%$ of the observed differences

Table 2

Total lengths (mm) for bluegill exposed to various air exposures across three water temperatures

\begin{tabular}{|c|c|c|c|}
\hline Temperature $\left({ }^{\circ} \mathrm{C}\right)$ & Air exposure duration (s) & $n$ & Total length (mm) \\
\hline 18.3 & $\mathrm{C}$ & 25 & $128.4 \pm 4.0^{\mathrm{d}, \mathrm{e}}$ \\
\hline 18.3 & 0 & 19 & $154.0 \pm 6.3^{\mathrm{a}, \mathrm{b}, \mathrm{c}, \mathrm{d}}$ \\
\hline 18.3 & 30 & 19 & $139.4 \pm 6.6^{\mathrm{a}, \mathrm{b}, \mathrm{c}, \mathrm{d}}$ \\
\hline 18.3 & 60 & 19 & $152.5 \pm 5.6^{\mathrm{a}, \mathrm{b}, \mathrm{c}, \mathrm{d}}$ \\
\hline 18.3 & 120 & 18 & $155.4 \pm 7.1^{\mathrm{a}, \mathrm{b}, \mathrm{c}, \mathrm{d}}$ \\
\hline 18.3 & 240 & 18 & $163.7 \pm 4.9^{\mathrm{a}, \mathrm{b}, \mathrm{c}}$ \\
\hline 18.3 & 480 & 18 & $140.1 \pm 5.7^{\mathrm{a}, \mathrm{b}, \mathrm{c}, \mathrm{d}}$ \\
\hline 18.3 & 960 & 18 & $147.1 \pm 5.6^{\mathrm{a}, \mathrm{b}, \mathrm{c}, \mathrm{d}}$ \\
\hline 22.8 & $\mathrm{C}$ & 21 & $152.4 \pm 10.7^{\mathrm{a}, \mathrm{b}, \mathrm{c}, \mathrm{d}}$ \\
\hline 22.8 & 0 & 20 & $157.1 \pm 6.3^{\mathrm{a}, \mathrm{b}, \mathrm{c}, \mathrm{d}}$ \\
\hline 22.8 & 30 & 20 & $144.3 \pm 6.8^{\mathrm{a}, \mathrm{b}, \mathrm{c}, \mathrm{d}}$ \\
\hline 22.8 & 60 & 20 & $163.8 \pm 6.3^{\mathrm{a}, \mathrm{b}}$ \\
\hline 22.8 & 120 & 20 & $162.5 \pm 6.6^{\mathrm{a}, \mathrm{b}, \mathrm{c}}$ \\
\hline 22.8 & 240 & 20 & $150.3 \pm 8.8^{\mathrm{a}, \mathrm{b}, \mathrm{c}, \mathrm{d}}$ \\
\hline 22.8 & 480 & 20 & $161.3 \pm 6.6^{\mathrm{a}, \mathrm{b}, \mathrm{c}}$ \\
\hline 22.8 & 960 & 20 & $167.0 \pm 7.4^{\mathrm{a}}$ \\
\hline 27.4 & $\mathrm{C}$ & 14 & $95.5 \pm 3.5^{\mathrm{e}}$ \\
\hline 27.4 & 0 & 15 & $139.7 \pm 8.1^{\mathrm{a}, \mathrm{b}, \mathrm{c}, \mathrm{d}}$ \\
\hline 27.4 & 30 & 15 & $127.7 \pm 6.3^{\mathrm{b}, \mathrm{c}, \mathrm{d}, \mathrm{e}}$ \\
\hline 27.4 & 60 & 15 & $125.8 \pm 6.9^{\mathrm{c}, \mathrm{d}, \mathrm{e}}$ \\
\hline 27.4 & 120 & 15 & $145.8 \pm 7.3^{\mathrm{a}, \mathrm{b}, \mathrm{c}, \mathrm{d}}$ \\
\hline 27.4 & 240 & 14 & $147.5 \pm 7.3^{\mathrm{a}, \mathrm{b}, \mathrm{c}, \mathrm{d}}$ \\
\hline 27.4 & 480 & 14 & $141.8 \pm 9.0^{\mathrm{a}, \mathrm{b}, \mathrm{c}, \mathrm{d}}$ \\
\hline 27.4 & 960 & 15 & $141.3 \pm 9.0^{\mathrm{a}, \mathrm{b}, \mathrm{c}, \mathrm{d}}$ \\
\hline
\end{tabular}

Dissimilar letters indicate significantly different $(P<0.05)$ values within an air exposure treatments at the three different temperatures $($ two-way ANOVA; d.f. $=14$, $F=1.80, P=0.037$; Tukey's HSD post hoc). 

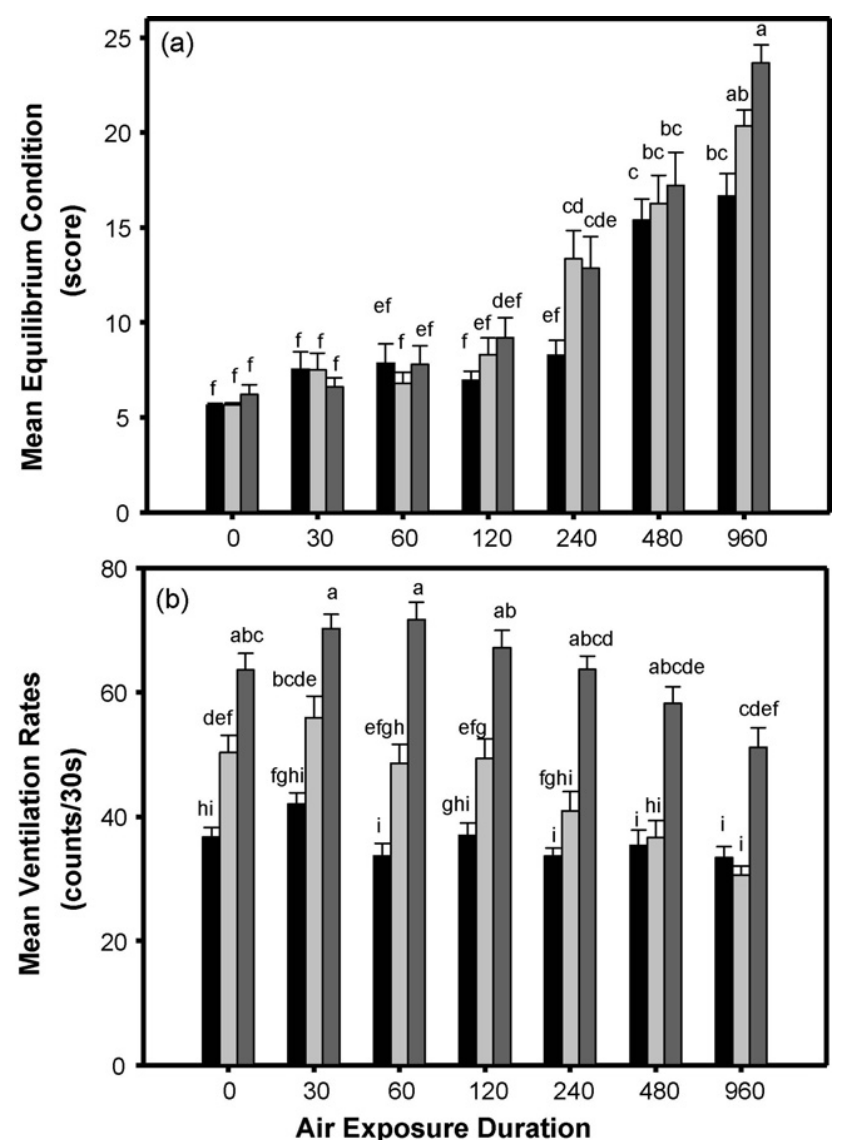

(s)

Fig. 1. Interactive effects between air exposure and water temperature treatment on response variables analyzed by two-way ANOVA's: (a) Equilibrium score (d.f. $=12, F=2.4, P=0.006$ ) and (b) Opercular counts (d.f.=12, $F=2.7, \mathrm{P}=0.001)$. Dissimilar letters represent significant differences $(P<0.05)$ between groups (Tukey's HSD post hoc test). (Dark bars $=18.2^{\circ} \mathrm{C}$, light-grey bars $=22.8^{\circ} \mathrm{C}$ and grey bars $=27.4{ }^{\circ} \mathrm{C}$ ).

(20 of the 28 observed differences in size between treatment groups; Tukey's HSD post hoc; Table 2).

\subsection{Behavioural responses}

The water temperature by air exposure interaction was significant for equilibrium score (two-way ANOVA; d.f. $=12 ; F=2.4$; $P=0.006$; Figs. 1 and $2 \mathrm{a}$; Table $3 \mathrm{a}$ ), and ventilation rate (twoway ANOVA; d.f. $=12, F=2.7, P=0.001$; Figs. 1 and $2 b$; Table 3b). Specifically, fish exposed to the warmest water temperature treatment and subjected to the longest air exposure durations had the highest equilibrium scores post-treatment (Fig. 2a). The water temperature by air exposure interaction was not significant for the time to recover from equilibrium loss (two-way ANOVA; d.f. $=12 ; F=1.7 ; P=0.065$; Table 3c). However, the time fish required to recover from equilibrium loss increased significantly with both water temperature and air exposure duration independently (temperature: d.f. $=2, F=11.0$, $P<0.0001$; air exposure: ANOVA; d.f. $=6, F=29.6, P<0.0001$; Fig. 3). Following equilibrium loss, fish generally required longer recovery durations with increasing water temperatures
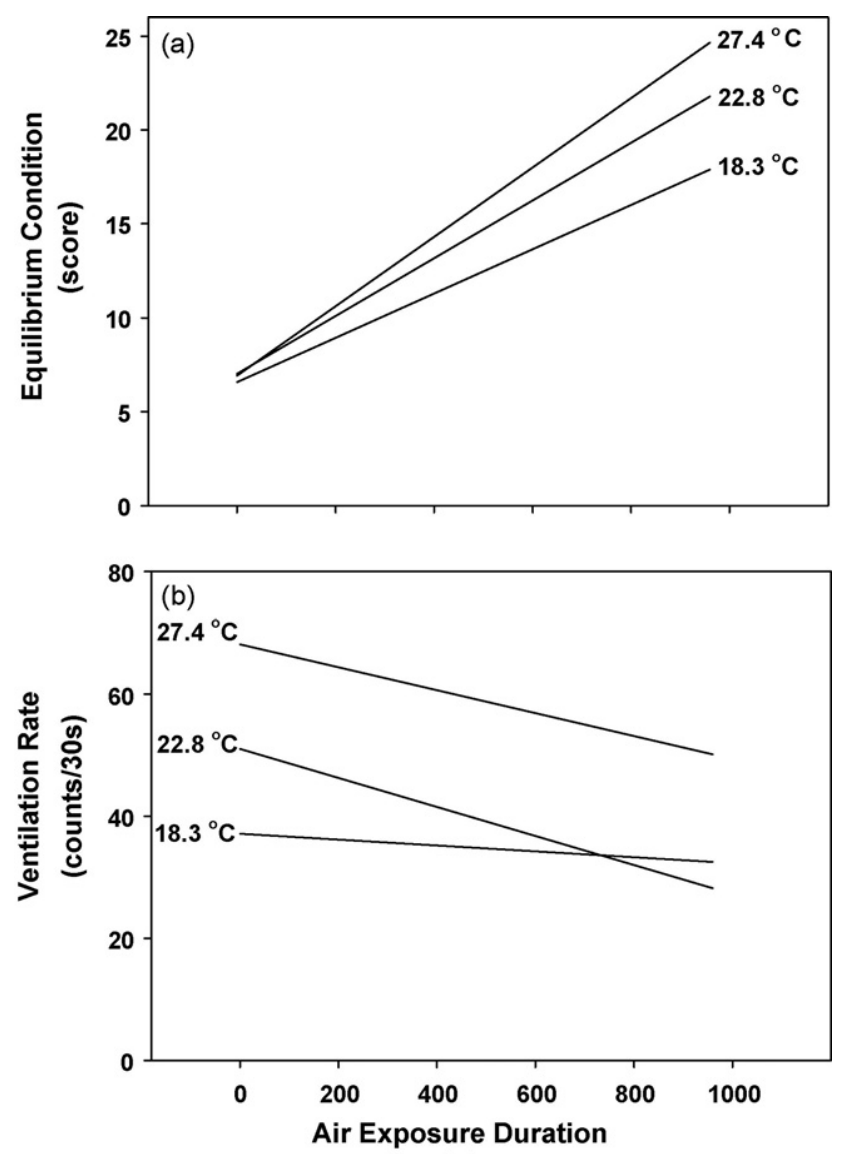

(s)

Fig. 2. Visualization of the interactive effects between air exposure and water temperature treatment on response variables analyzed by two-way ANOVA's: (a) Equilibrium score (d.f. $=12, F=2.4, P=0.006$ ) and (b) Ventilation rate (d.f. $=12$, $F=2.7, P=0.001)$. Lines are fitted as regression lines to illustrate the interaction.

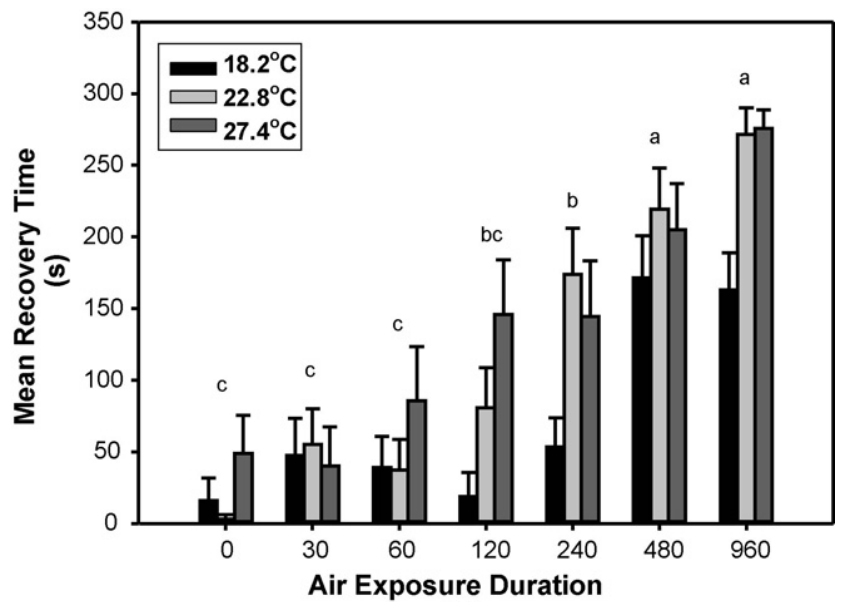

(s)

Fig. 3. Effects of air exposure and water temperature treatment on time to needed to recover from equilibrium loss (temperature; d.f. $=2, F=11.0, P<0.0001$; air exposure; d.f. $=6, F=29.6, P<0.0001)$. Dissimilar letters represent significant differences $(P<0.05)$ between air exposure groups (Tukey's HSD post hoc test). 
Table 3

Two-way analysis of variance comparing air exposure group and temperature treatment for three behavioural response variables

\begin{tabular}{|c|c|c|c|c|c|}
\hline Factor & Source & d.f. & Sum of squares & $F$ ratio & $P$-value \\
\hline \multirow{3}{*}{ (a) Condition } & Temperature & 2 & 288.1 & 8.2 & 0.0003 \\
\hline & Air exposure & 6 & 9133.3 & 86.5 & $<0.0001$ \\
\hline & Air exposure $\times$ Temperature & 12 & 499.5 & 2.4 & 0.0062 \\
\hline \multirow{3}{*}{ (b) Ventilation } & Temperature & 2 & 43744.3 & 193.7 & $<0.0001$ \\
\hline & Air exposure & 6 & 10628.3 & 15.7 & $<0.0001$ \\
\hline & Air exposure $\times$ Temperature & 12 & 3716.2 & 2.7 & 0.0014 \\
\hline \multirow{3}{*}{ (c) Recovery } & Temperature & 2 & 256438.8 & 11.0 & $<0.0001$ \\
\hline & Air exposure & 6 & 2064236.6 & 29.6 & $<0.0001$ \\
\hline & Air exposure $\times$ Temperature & 12 & 237468.0 & 1.7 & 0.0649 \\
\hline
\end{tabular}

Italicized values represent those that are significant at $P<0.05$.

(means $[ \pm$ S.E.], $71 \pm 9.8,120 \pm 12.0$ and $135 \pm 14.0 \mathrm{~s}$, respectively).

\subsection{Mortality}

Across the three sampling dates, no significant immediate mortality was observed $\left(N_{18.3{ }^{\circ} \mathrm{C}}=0, N_{22.8}{ }^{\circ} \mathrm{C}=0, N_{27.4}{ }^{\circ} \mathrm{C}=2\right)$. The two fish that died immediately at the warmest temperature were both in the 960 s treatment group. Negligible delayed mortality was observed during the two lower temperature treatments irrespective of air exposure duration $\left(18.3^{\circ} \mathrm{C}, 2.6 \%\right.$ mortality; $22.8^{\circ} \mathrm{C}, 1.9 \%$; Table 1). Upon release, surviving fish in the two cooler temperature treatments appeared to be in good condition at the end of the $48 \mathrm{~h}$ monitoring period. During the third sampling period at $27.4{ }^{\circ} \mathrm{C}, 39 \%$ of all sampled fish died in the SMT. Specifically, fish subjected to $960 \mathrm{~s}$ of air exposure showed the highest levels of mortality followed by the 480 and 240 s treatment groups (Fig. 4). In addition, survivorship analysis showed that there was a significant difference in the length of time to death among the air exposure groups on the last temperature treatment day (Wilcoxon univariate survivor analysis; d.f. $=7$, $X^{2}=46.3, P<0.0001$; Fig. 5), with the fish from the 960 s treatment group succumbing to mortality at a faster rate than all other

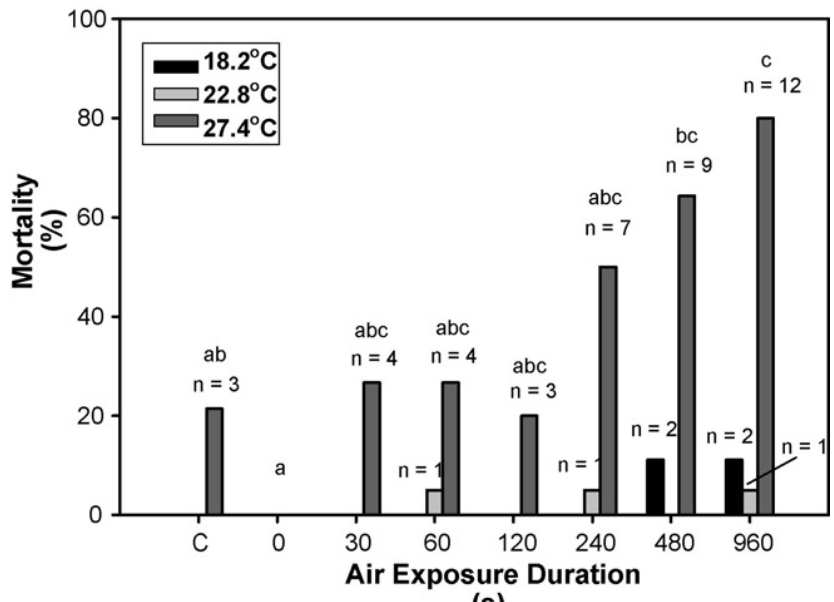

(s)

Fig. 4. Observed delayed mortality $(\%)$ relative to water temperature treatments. Dissimilar letters indicate significant differences $(P<0.05)$ in mortalities on the highest temperature treatment (i.e., $27.4^{\circ} \mathrm{C}$; contingency table analysis).

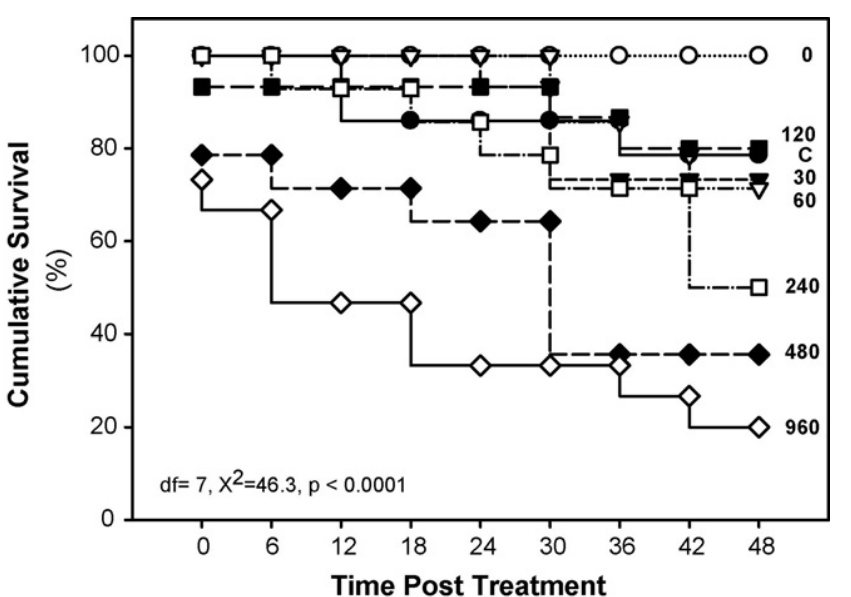

(h)

Fig. 5. Survival (percent during $48 \mathrm{~h}$ monitoring period) of bluegill angled during the highest temperature treatment $\left(27.4^{\circ} \mathrm{C}\right)$ and exposed to different air exposure durations.

treatment groups, and the $480 \mathrm{~s}$ group dying sooner than the $60 \mathrm{~s}$ group (ANOVA, d.f. $=6, F=2.5, P=0.039$ with Tukey's HSD post hoc). At the end of the $48 \mathrm{~h}$ monitoring period at the $27.4{ }^{\circ} \mathrm{C}$ treatment, many of the fish that were still alive were moribund and would likely have died after release.

There was no significant difference in size between the fish that lived or died at $27.4^{\circ} \mathrm{C}$ in the $240 \mathrm{~s}$ ( $t$-test, $t=2.18$, d.f. $=12$, $P=0.280)$ and $480 \mathrm{~s}(t$-test, $t=2.23$, d.f. $=10, P=0.380)$ groups. Due to limited mortality during the two lowest temperature treatments and low ratios of mortalities to living fish among other air exposure groups on the highest water temperature treatment day $\left(27.4{ }^{\circ} \mathrm{C}\right)$, similar analyses were not possible.

\section{Discussion}

Five primary factors (angling duration, air exposure duration, angling during extreme water temperature periods, gear type and angling during reproductive periods; summarized by Cooke and Suski, 2005) are regarded as those that can influence stress and mortality associated with an angling event. These stressors can lead to a host of physiological and behavioural changes and may result in either direct or indirect morality (Muoneke and Childress, 1994; Cooke and Suski, 2005). Although these 
factors have been demonstrated as stressors by various studies, they are most often studied singularly and when multiple stressors are considered they are typically independently analyzed (e.g., Muoneke, 1992; Diodati and Richards, 1996; Dempson et al., 2002; reviewed in Arlinghaus et al., 2007). The idea that stressors can be interactive is better understood in a commercial fishing/bycatch context (e.g., Davis et al., 2001; Davis and Olla, 2001, 2002). For example, Davis et al. (2001) revealed that following simulated capture by hooking, plasma cortisol and lactate increased with air exposure duration for sablefish (Anoplopoma fimbria), and when temperature was high, mortalities were observed. The current research attempted to address two factors (air exposure and water temperature) associated with C\&R stress and examined the interaction that these two variables may have on fish behaviour and mortality in the context of recreational C\&R fisheries. As predicted, an interaction between air exposure and water temperature was identified when examining sublethal behavioural disturbance in bluegill. Behavioural disturbance was shown to be higher when both stressors were combined than if the stressors were applied independently. The interaction of these two factors on sublethal characteristics such as ventilation and equilibrium condition was expected given the multiplicative nature of stress.

Behavioural changes are sensitive indicators of organismal stress and can severely impact organism function (Schreck et al., 1997). Short-term behavioural changes may be a very accurate predictor of ultimate recovery or mortality of a released individual (A.J. Danylchuk et al., 2007; S.E. Danylchuk et al., 2007). The present results show that both the probability of equilibrium loss and the length of time required for fish to recover equilibrium are dependent on both air exposure and water temperature (Table 3). Other studies have also identified similar behavioural changes following stress such as impaired swimming activity (e.g., Mitton and McDonald, 1994; Cooke and Philipp, 2004; Schreer et al., 2005; S.E. Danylchuk et al., 2007). Even relatively small levels of stress, caused by an increase in water temperature or air exposure, can induce quantifiable sublethal behavioural changes. Besides the occurrence of mortality, these behavioural changes could have impacts on fish reproductive effort (Suski et al., 2003). These sublethal behavioural changes seemed to be good predictors of mortality, as those fish subjected to the higher levels of temperature increase and air exposure also had the highest levels of mortality.

In the present study, direct mortality occurred at the high ambient water temperature $\left(27.4^{\circ} \mathrm{C}\right)$ within all experimental air exposure groups, with the rate and proportion increasing with increasing air exposure duration. The highest water temperature produced an average mortality of nearly $40 \%$ across all air exposure treatment groups and as high as $80 \%$ at the highest air exposure treatment (Table 1; Fig. 4). This mortality was observed almost exclusively during the delayed mortality monitoring period as only two fish died within the first 5 min post-air exposure (both of which died during the highest temperature treatment $\left.\left[27.4^{\circ} \mathrm{C}\right]\right)$. This observation, combined with the fact that mortality tended to occur several hours after the angling event, points out that a perceived successful C\&R event may in fact be unsuccessful if delayed mortality occurs. Even when anglers allow fish that are displaying sublethal effects to recover, these fish may succumb to their stress hours or days later (Black, 1958; Wood et al., 1983; Wilde, 1998; Ferguson and Tufts, 1992). Thus, delayed mortality is an important management concern, especially at high ambient water temperatures, because $\mathrm{C} \& \mathrm{R}$ fishing hinges on the assumption that recovered fish will not die; if these fish die hours later, then this C\&R effort was unsuccessful. Consequently, some fisheries are closed to anglers during periods of high water temperatures (e.g., Atlantic salmon [Salmo salar] fisheries along the east coast of Canada (Wilkie et al., 1996; Fisheries and Oceans Canada, 1998; Tufts et al., 2000). Educating anglers about the need to minimize stress associated with angling, particularly at high temperatures, would alleviate the need for these regulations in other fisheries.

Although not the focus of this study, other work has revealed that the stress associated with air exposure and high water temperature can cause a host of physiological changes in fish. Furthermore, the physiological changes that fish may experience after an angling event may also contribute to mortality, although there are few direct field assessments that link physiological disturbance and mortality (see Cooke and Schramm, 2007 for discussion). In a lab study, Ferguson and Tufts (1992) evaluated the extra-cellular acid-base recovery of rainbow trout (Oncorhynchus mykiss) and noted that the acid base disturbance seemed to be approaching pre-disturbance levels when mortalities were observed. Metabolic changes or increases after exercise in teleost fish can take $8-12 \mathrm{~h}$ to return to pre-exercise levels (Kieffer, 2000), while cardiac changes often take 1-2 h to return to basal levels (Heath and Pritchard, 1962) with the duration of the recovery periods proportional to the magnitude of the stressor (Kieffer, 2000; Cooke et al., 2001, 2002a). Interestingly, mortality in our study was spread across the $48 \mathrm{~h}$ monitoring period and not exclusively during the period when fish would be expected to be recovering from the handling and angling stress. However, we did observe that fish exposed to longer durations of air exposure took longer to recover (behaviourally) relative to shorter exposure durations, particularly at high water temperatures. Future studies should attempt to integrate more measures of behaviour and physiology to understand their combined influence on the fate of individual fish following angling-induced stress.

Sublethal effects similar to those observed in this study have been linked to post-release mortality among other economically valuable game fish (principally bonefish [Albula spp.]) through external mechanisms such as predation. A.J. Danylchuk et al. (2007) found that predator-induced mortality of bonefish (Albula vulpes) associated with a C\&R angling event occurred within the first hour of release. It is likely that this is the time when sublethal behavioural and physiological changes are maximal, and as a result fish may be most vulnerable to predation. However, significant delayed mortality (not associated with predation) was also noted, indicating that some fish were unable to fully recover from the experimental stress or that there was a discordance between physiological condition and mortality. In a similar study S.E. Danylchuk et al. (2007) determined that angled bonefish (Albula vulpes) had a $17 \%$ chance of post-release predation mortality compared to only $5 \%$ post-release predation mortality when seined. Particularly, fish that suffered equilibrium loss (defined 
by a fish being unable to swim away immediately upon release but instead rolling on its side or "nose diving" toward the substrate) caused by the stress associated with an angling event were six times more likely to suffer from predation by piscivorous marine fishes than those released fish exhibiting no equilibrium loss. The probability that a fish was going to lose equilibrium was correlated with the duration of handling time, which can also be measured as air exposure (A.J. Danylchuk et al., 2007; S.E. Danylchuk et al., 2007). Similar indices of equilibrium loss were measured in the present study and fish showed increased levels of impairment when increased air exposure durations were coupled with high ambient water temperatures. Cooke and Philipp (2004) found that bonefish (Albula spp.) can face close to $40 \%$ predation mortality post-release, dependant on local predator densities. Nevertheless, post-release predation is likely caused from the behavioural and physiological effects induced from the angling event and should be viewed as a concern when considering the C\&R fishing as a conservation practice (Cooke et al., $2002 \mathrm{~b}$ ). Although these conclusions have been derived from a marine model, it is important to consider behavioural changes in temperate situations as piscivorous and avian predators are also present in these systems. Many studies have focused primarily on the direct and immediate mortality associated with a C\&R event (see Muoneke and Childress, 1994), however, delayed mortality can also be associated with $\mathrm{C} \& \mathrm{R}$ angling. Increased predation mortality associated with $\mathrm{C} \& \mathrm{R}$ fishing has not been quantified in a temperate system but may be warranted for certain species (Cooke et al., 2002b). For example, predation issues are of specific concern for those game fish species that are not apex predators, such as the bluegill or any species/individual that is small enough to be attacked by an avian predator.

One of the methods used to quantify sublethal impacts following angling was ventilation rate. Using similar methods, Sutterlin (1969) quantified ventilation rates of pumpkinseed, finding that they doubled during exercise, followed by a marked decline during a $5 \mathrm{~min}$ recovery time. These ventilatory increases are necessary to facilitate additional water flow over the gills and presumably affect the rate of $\mathrm{O}_{2}$ uptake. During recovery, blood acidosis stimulates ventilation and enables the fish to meet the demands of 'excess post-exercise oxygen consumption' (Wood, 1991). Results from the present study reveal that fish subjected to intermediate durations of air exposure had the highest ventilation rates after $5 \mathrm{~min}$, whereas fish subjected to the shortest and longest durations of air exposure had the lowest ventilation rates. Fish that are angled at low water temperatures and subjected to shorter durations of air exposure exhibited the lowest ventilation rates. This observation may be due to the fact that these individuals incurred a lower physiological disturbance associated with the lack of air exposure coupled with the low metabolism at low temperatures. At the highest water temperature, lengthy air exposures lead to a decrease in ventilation rates for two proposed reasons (a) the depth of ventilation may be increasing and was not quantified in this experiment (Heath, 1973) and more importantly, (b) fish are too stressed and oxygen deprived to physically move their operculum, however this relationship is poorly understood. There are two pieces of evidence that may explain the observed increase in ventilation rates among the intermediate air exposure groups; exercise followed by air exposure results in the extracellular acidosis and lactate increase in the blood (Ferguson and Tufts, 1992). Higher water temperatures decrease the dissolved oxygen present in the water, forcing fish to increase their rate of ventilation (Heath, 1973). Fish held at elevated water temperatures are presumably under additional stress compared to fish in lower water temperatures, even before an angling event occurs. Therefore, the increase in both of these variables (air exposure and water temperature) exacerbates the effect on fish and explains the sublethal observations quantified in the present study. From a management perspective, fish released with either severely elevated or depressed (nearly absent) ventilation rates are a concern, as these fish are presumably exhibiting a stress response that may be indicative of future mortality. It is important to note that some concern has surrounded the use of ventilation rates as an indicator of fish condition (see Barreto and Volpato, 2004) because there seems to be significant individual plasticity in response to a stressor.

In this study, almost $22 \%$ of the seined control fish died on the last temperature treatment day $\left(27.4^{\circ} \mathrm{C}\right)$. This can be linked to two possible phenomena. First, capture via seine net can be a major source of stress and injury that is likely to be exacerbated at high water temperatures. Barthel et al. (2003) concluded that fish captured using landing nets had higher dermal disturbance and increased fin abrasion, relative to control and hand landed fish. This abrasion and scale removal may increase opportunistic pathogenic infections (e.g., Saprolegnian lesions) at high water temperatures and may contribute to faster mortality. As noted in results, many of the fish that were released after the $48 \mathrm{~h}$ monitoring period on the highest temperature treatment $\left(27.4{ }^{\circ} \mathrm{C}\right)$ appeared to be moribund and had lesions across fins and body despite the fact that they were clinically alive according to the definition (ventilation present) used in this study. Thompson and Hunter (1973) reported mortalities of $40 \%$ when nets removed scales and up to $80 \%$ when addition stress, such as air exposure, was applied to fish that had lost scales in commercial models. Notably, control fish that were seined in the present study spent a considerable amount of time in the seine bag while fish were being processed. It is possible that the stress associated with crowding and abrasion over the time period that fish were confined within the seine caused high mortalities in this group at the highest water temperature $\left(27.4^{\circ} \mathrm{C}\right)$. Additionally, size differences among treatments (seined fish were significantly smaller than the majority of other treatment groups) could also be partially responsible for the mortality seen in this treatment group. Cooke et al. (2003) found that the mortality of hooked bluegill seemed to be negligible, but when it did occur the fish were small relative to other fish processed in their study.

\subsection{Conclusions and management implications}

Globally, billions of fish are released each year by anglers and C\&R fishing is prevalent across North America and other parts of the world (Cooke and Cowx, 2004; summarized in Arlinghaus et al., 2007). Due to the importance of this technique with respect to 
fisheries and economic conservation, $\mathrm{C} \& \mathrm{R}$ research has received more and more attention. Although it has been necessary to identify the primary factors that cause fish stress during an angling event (for example air exposure duration), evaluating these stressors in combination with each other is important to improve the quality of fisheries management regulations and ultimately angler knowledge. Fish are exposed to many factors during an angling event and this study demonstrated that the stress associated with two factors (water temperature and air exposure) may be greater than it would be if the stressors were applied independently. Even when the stress is small by comparison, fish experience quantifiable changes in ventilation rate, equilibrium condition and equilibrium recovery time. These sublethal effects help predict the probability of mortality that is directly associated with the stress induced by an angling event. This represents a deficient area of study, particularly in temperate models, and should be considered when evaluating the consequences of C\&R. Management regimes in multiple locations currently factor in guidelines on air exposure durations (i.e., recommending that anglers reduce stress during high water temperatures; Pelletier et al., 2007). Additionally, some jurisdictions close fisheries during periods of high water temperature wherein recreational angling would result in mortality of angled individuals (Wilkie et al., 1996; Fisheries and Oceans Canada, 1998; Tufts et al., 2000). To date, no management jurisdictions explicitly comment on the interaction between these factors (Pelletier et al., 2007). Consideration of these interactions, and subsequent regulations or recommendations, should be considered to increase the survivorship of individual fish subject to $C \& R$ angling.

\section{Acknowledgements}

This paper represents an undergraduate thesis project conducted by Andrew Gingerich to fulfill the requirements for an undergraduate degree at Carleton University. The authors thank Amanda O'Toole, Zack Whynot, Robyn Walker, Ashley Graham, Lisa Thompson and Thomas Klefoth for assistance with data collection. We also thank the staff of the Queen's University Biology Station for logistic support. Research permits were provided by the Ontario Ministry of Natural Resources and animal care approvals were granted by Carleton University and Queen's University on behalf of the Canadian Council for Animal Care. Kringen Henein and several anonymous reviewers kindly commented earlier versions of the manuscript. Aspects of this research were supported by funds from Carleton University, the Canadian Foundation for Innovation, the Ontario Research Fund, the Rainy Lake Fisheries Charity Trust and the Natural Sciences and Engineering Research Council of Canada.

\section{References}

Anderson, W.G., Booth, R., Beddow, T.A., McKinley, R.S., Finstad, B., Okland, F., Scruton, D., 1998. Remote monitoring of heart rate as a measure of recovery in angled Atlantic salmon, Salmo salar (L.). Hydrobiologia 371/372, 233-240.

Arlinghaus, R., Hallermann, J., 2007. Effects of air exposure on mortality and growth of undersized pikeperch, Sander lucioperca, at low water tempera- tures with implications for catch-and-release fishing. Fish. Manage. Ecol. $14,155-160$.

Arlinghaus, R., Cooke, S.J., Lyman, J., Policansky, D., Schwab, A., Suski, C.D., Sutton, S.G., Thorstad, E.B., 2007. Understanding the complexity of catch-and-release in recreational fishing: an integrative synthesis of global knowledge from historical, ethical, social, and biological perspectives. Rev. Fish. Sci. 15, 75-167.

Barreto, E.R., Volpato, G.L., 2004. Caution for using ventilatory frequency as an indicator of stress in fish. Behav. Proc. 66, 43-51.

Barthel, B.L., Cooke, S.J., Suski, C.D., Philipp, D.P., 2003. Effects of landing net mesh type on injury and mortality in a freshwater recreational fishery. Fish. Res. 63, 275-282.

Bartholomew, A., Bohnsack, J.A., 2005. A review of catch-and-release angling mortality with implications for no-take reserves. Rev. Fish Biol. Fish. 15, 129-154.

Black, E.C., 1958. Hyperactivity as a lethal factor in fish. J. Fish. Res. Board Can. 15, 573-586.

Boutilier, R.G., 1990. Control and co-ordination of gas exchange in bimodal breathers. In: Boutilier, R.G. (Ed.), Advances in Comparative and Environmental Physiology 6: Vertebrate Gas Exchange: From Environment to Cell. Springer-Verlag, New York, pp. 280-346

Conover, G.A., Sheehan, R.J., 1999. Survival, growth and mark persistence in juvenile black crappies marked with fin clips. N. Am. J. Fish. Manage. 19, 824-827.

Cooke, S.J., Cowx, I.G., 2004. The role of recreational fisheries in global fish crises. BioScience 54, 857-859.

Cooke, S.J., Philipp, D.P., 2004. Behavior and mortality of caught-and-released bonefish (Albula spp.) in Bahamian waters with implications for a sustainable recreational fishery. Biol. Conserv. 118, 599-607.

Cooke, S.J., Schramm Jr., H.L., 2007. Catch-and-release science and its application to conservation and management of recreational fisheries. Fish. Manage. Ecol. 14, 73-79.

Cooke, S.J., Suski, C.D., 2005. Do we need species specific guidelines for catch-and-release recreational angling to effectively conserve diverse fishery resources? Biodiv. Conserv. 14, 1195-1209.

Cooke, S.J., Philipp, D.P., Dunmall, K.M., Schreer, J.F., 2001. The influence of terminal tackle on injury, handling time, and cardiac disturbance of rock bass. N. Am. J. Fish. Manage. 21, 333-342.

Cooke, S.J., Schreer, J.F., Wahl, D.H., Philipp, D.P., 2002a. Physiological impacts of catch-and-release angling practices on largemouth bass and smallmouth bass. Am. Fish. Soc. Symp. 31, 489-512.

Cooke, S.J., Schreer, J.F., Dunmall, K.M., Philipp, D.P., 2002b. Strategies for quantifying sublethal effects of marine catch-and-release angling-insights from novel freshwater applications. Am. Fish. Soc. Symp. 30, 121-134.

Cooke, S.J., Suski, C.D., Barthel, B.L., Ostrand, K.G., Tufts, B.L., Philipp, D.P., 2003. Injury and mortality induced by four hook types on bluegill and pumpkinseed. N. Am. J. Fish. Manage. 23, 883-893.

Cooke, S.J., Barthel, B.L., Suski, C.D., Siepker, M.J., Philipp, D.P., 2005. Influence of circle hook size on hooking efficiency, injury, and size selectivity of bluegill with comments on circle hook conservation benefits in recreational fisheries. N. Am. J. Fish. Manage. 25, 211-219.

Danylchuk, A.J., Danylchuk, S.E., Cooke, S.J., Goldberg, T.L., Koppelman, J., Philipp, D.P., 2007. Post-release mortality of bonefish (Albula vulpes) exposed to different handling practices in South Eleuthera, Bahamas. Fish. Manage. Ecol. 14, 149-154.

Danylchuk, S.E., Danylchuk, A.J., Cooke, S.J., Goldberg, T.L., Koppelman, J., Philipp, D.P., 2007. Effects of recreational angling on the post-release behavior and predation of bonefish (Albula vulpes): the role of equilibrium status at time of release. J. Exp. Mar. Biol. Ecol. 346, 127-133.

Davis, M.W., Olla, B.L., 2001. Stress and delayed mortality induced in Pacific halibut Hippoglossus stenolepis by exposure to hooking, net towing, elevated sea water temperature and air: implications for management of bycatch. N. Am. J. Fish. Manage. 21, 725-732.

Davis, M.W., Olla, B.L., 2002. Mortality of lingcod towed in a net is related to fish length, seawater temperature and air exposure: a laboratory bycatch study. N. Am. J. Fish. Manage. 22, 1095-1104.

Davis, M.W., Olla, B.L., Schreck, C.B., 2001. Stress induced by hooking, net towing, elevated sea water temperature and air in sablefish: lack of concor- 
dance between mortality and physiological measures of stress. J. Fish Biol. $58,1-15$.

Dempson, J.B., Furey, G., Bloom, M., 2002. Effects of catch and release angling on Atlantic salmon, Salmo salar L., of the Conne River, Newfoundland. Fish. Manage. Ecol. 9, 139-147.

Diodati, P.J., Richards, R.A., 1996. Mortality of striped bass hooked and released in salt water. Trans. Am. Fish. Soc. 125, 300-307.

Dunmall, K.M., Cooke, S.J., Schreer, J.F., McKinley, R.S., 2001. The effect of scented lures on the hooking injury and mortality of smallmouth bass caught by novice and experienced anglers. N. Am. J. Fish. Manage. 21, 242-248.

Ferguson, R.A., Tufts, B.L., 1992. Physiological effects of brief air exposure in exhaustively exercised rainbow trouts (Oncorhynchus mykiss): implications for "catch and release" fisheries. Can. J. Fish. Aquat. Sci. 49, 1157-1162.

Fisheries and Oceans Canada, 1998. Effects of hook-and-release angling practises-Atlantic salmon. Department of Fisheries and Oceans Stock Status Report D0-03, Ottawa, Canada, 7 pp.

Fry, F.E.J., 1971. The effect of environmental factors on the physiology of fish. In: Hoar, W.S., Randall, D.J. (Eds.), Fish Physiology, Environmenta Relations and Behavior, vol. VI. Academic Press, New York, pp. 1-98.

Heath, A.G., 1973. Ventilatory responses of teleost fish to exercise and thermal stress. Am. Zool. 13, 491-503.

Heath, A.G., Pritchard, A.W., 1962. Changes in the metabolic rate and blood lactic acid of bluegill sunfish, Lepomis macrochirus, Raf., following severe muscular activity. Physiol. Zool. 35, 323-329.

Kieffer, J.D., 2000. Limits to exhaustive exercise in fish. Comp. Biochem. Physiol. 126A, 161-179.

Killen, S.S., Suski, C.D., Cooke, S.J., Philipp, D.P., Tufts, B.L., 2006. Factors contributing to the physiological disturbance in walleyes during live-release angling tournaments. Trans. Am. Fish. Soc. 135, 557-569.

Mitton, C.J.A., McDonald, D.G., 1994. Consequences of pulsed DC electrofishing and air exposure to rainbow trout (Oncorhynchus mykiss). Can. J. Fish. Aquat. Sci. 51, 1791-1798.

Muoneke, M.I., 1992. Seasonal hooking mortality of bluegill caught on natural baits. N. Am. J. Fish. Manage. 12, 645-649.

Muoneke, M.I., Childress, W.M., 1994. Hooking mortality: a review for recreational fisheries. Rev. Fish. Sci. 2, 123-156.

Pelletier, C.A., Hanson, K.C., Cooke, S.J., 2007. Do catch-and-release guidelines from state and provincial fisheries agencies in North America conform to scientifically-based best practices? Environ. Manage. 39, 760-773.

Prosser, C.L., 1991. Environmental and Metabolic Animal Physiology. WileyLiss, New York.

Ross, M.R., Hokenson, S.R., 1997. Gulf of Maine fishery for northern Shrimp pandalus borealis. N. Am. J. Fish. Manage. 1, 902-909.

Schreck, C.B., Olla, B.L., Davis, M.W., 1997. Behavioural responses to stress. In: Iwama, G.K., Pickering, A.D., Sumpter, J.P., Schreck, C.B. (Eds.), Fish
Stress and Health in Aquaculture, Society for Experimental Biology Series 62. Cambridge University Press, Cambridge, pp. 145-170.

Schreer, J.F., Cooke, S.J., McKinley, R.S., 2001. Cardiac response to variable forced exercises at different temperatures - an angling simulation for smallmouth bass. Trans. Am. Fish. Soc. 130, 783-795.

Schreer, J.F., Resch, D., Gately, M., Cooke, S.J., 2005. Swimming performance of brook trout following simulated catch-and-release angling: looking for air exposure thresholds. N. Am. J. Fish. Manage. 25, 1513-1517.

Somero, G.N., Hofmann, G.E., 1996. Temperature thresholds for protein adaptation: when does temperature change start to 'hurt'? Soc. Exp. Biol. Semin. Ser 16, 1-24.

Suski, C.D., Svec, J.H., Ludden, J.B., Phelan, F.J.S., Philipp, D.P., 2003. The effect of catch-and-release angling on the parental care behavior of male smallmouth bass. Trans. Am. Fish. Soc. 132, 210-218.

Suski, C.D., Killen, S.S., Cooke, S.J., Kieffer, J.D., Philipp, D.P., Tufts, B.L., 2004. Physiological significance of the weigh-in during live-release angling tournaments for largemouth bass. Trans. Am. Fish. Soc. 133, 1291-1303.

Suski, C.D., Killen, S.S., Kieffer, J.D., Tufts, B.L., 2006. The influence of environmental temperature and oxygen concentration on the recovery of largemouth bass from exercise: implications for live-release angling tournaments. J. Fish Biol. 68, 120-136.

Sutterlin, A.M., 1969. Effects of exercise on cardiac and ventilation frequency in three species of freshwater teleosts. Physiol. Zool. 42, 36-52.

Thompson, R.B., Hunter, C.J., 1971. Viability of adult sockeye salmon that disentangle from gillnets. Int. North Pac. Fish. Comm. Annu. Rep., 107-109.

Thorstad, E.B., Naesje, T.F., Fiske, P., Finstad, B., 2003. Effects of hook removal on Atlantic salmon in the River Alta, Northern Norway. Fish. Res. 60, 293-307.

Tufts, B.L., Davidson, K., Bielak, A.T., 2000. Biological implications of "catchand-release" angling of Atlantic salmon. In: Whoriskey, F.G., Whelan, K.E. (Eds.), Managing Wild Atlantic Salmon. Atlantic Salmon Federation, St. Andrews, New Brunswick, pp. 195-225.

Wilde, G.R., 1998. Tournament-associated mortality in black bass. Fisheries 23 (10), 12-22.

Wilkie, M.P., Davidson, K., Brobbel, M.A., Kieffer, J.D., Booth, R.K., Bielak, A.T., Tufts, B.L., 1996. Physiology and survival of wild Atlantic salmon following angling in warm summer waters. Trans. Am. Fish. Soc. 125, 572-580.

Wilkie, M.P., Brobbel, M.A., Davidson, K., Forsyth, L., Tufts, B.L., 1997. Influences of temperature upon the post-exercise physiology of Atlantic salmon (Salmo salar). Can. J. Fish. Aquat. Sci. 54, 503-511.

Wood, C.M., 1991. Acid-base and ion balance, metabolism and their interactions, after exhaustive exercise in fish. J. Exp. Biol. 160, 285-308.

Wood, C.M., Turner, J.D., Graham, M.S., 1983. Why do fish die after severe exercise? J. Fish Biol. 22, 189-201.

Zar, J.H., 1984. Biostatistical Analysis. Prentice Hall, Englewood Cliffs, New Jersey. 